Boise State University

ScholarWorks

$1-1-2016$

\title{
The Search for a Plural America: Protestant and Enlightenment Authority in American History
}

Andrew Finstuen

Boise State University 


\section{Review Essay*}

\section{The Search for a Plural America: Protestant and Enlightenment Authority in American History}

Andrew Finstuen

Boise State University

A crisis of authority defines modernity. The crisis in the Christian West dates to the Reformation and the church-and-state conflicts based upon the question: whose Christianity? The crisis deepened during the Enlightenment as advances in science, reason, and technology changed the question: Christianity or not? By the 1960s, post-structuralism or postmodernity had posed the very question of authority and asserted competing authorities.

Out of the first two crises, America was born. Shaped by the forces of a plural Christian West and the Enlightenment, the founders constructed a nation steeped in the assumptions of both faith and reason. They balanced these authorities by disestablishing religion, providing for its free exercise, and creating three branches of government to obstruct runaway power.

For George Marsden, Francis A. McAnaney Professor Emeritus at the University of Notre Dame, the marriage of liberal Protestantism and Enlightenment principles held the country together for nearly two hundred years. In his The Twilight of the American Enlightenment: The 1950s and the Crisis of Liberal Belief (2013), Marsden argues that in the mid-twentieth century this formula began to fail. $\mathrm{He}$

\footnotetext{
" George Marsden, The Twilight of the American Enlightenment: The 1950s and the Crisis of Liberal Belief (New York: Basic Books, 2013). 264 pp. \$26.99 hb.
}

HTR 109:1 (2016) 144-155 
locates that failure in a liberal Protestantism that adapted to secular reason and became a loose approximation of the Christian faith. That left the Enlightenment as the proprietor of American public life and created the impression of increasing secularization.

These cultural riptides grew stronger in the 1960s. God was dead, a president and his brother were dead, Martin Luther King, Jr. was dead, citizens on American streets set ablaze by race riots were dead, and tens of thousands of Americans in Vietnam were dead. These events shook the American liberal Protestant-Enlightenment consensus. Women, blacks, gays, a secular left, a counterculture youth, and a new Christian right protested that the consensus had never been consensual.

These left turns and right turns spawned a set of culture wars that have dominated public life for the past five decades. For Marsden, these wars endured because neither liberal Protestantism nor conservative evangelical Protestantism nor the Enlightenment proved adequate for a plural America.

Weary of the fight, Marsden proposes an alternative approach to how we can live together. His plan for détente draws on the life and thought of Dutch theologianstatesman Abraham Kuyper (1837-1920). Kuyper was a force of nature. From the pastorate, he formed a new denomination of the Reformed church, co-founded a university, and established a political party. His political activity won him a seat in parliament and eventually the office of prime minister. In all of these activities, Kuyper recognized that religious and secular viewpoints not only coexisted but also would have to cooperate. To foster cooperation he argued, as Marsden notes, "that no one stands on neutral ground." Scientists and believers alike operated from non-objective "highest commitments." According to Marsden, Kuyper's orthodox Christianity plus his clear vision of competing religious and secular truths models an instructive pluralism. It avoids the liberal Protestant accommodation of modernity, the false universalism of Enlightenment thought, and the knee-jerk absolutism of conservative evangelicalism.

Where Marsden sees a problem in the marriage of liberal Protestantism and the Enlightenment, atheist David Hollinger in After Cloven Tongues of Fire: Protestant Liberalism in Modern American History (2013) sees a solution. Hollinger, Preston Hotchkis Professor Emeritus at the University of California, Berkeley, celebrates liberal Protestantism's adaptation to modern knowledge. The union of Enlightenment values and liberal belief realized the idealism of a free, equal, and protected society. For Hollinger, liberal Protestantism's waning influence in the contemporary moment is hardly an event to be mourned. They "won," after all, delivering America to greater inclusivity and opportunity and an Enlightenment sensibility to sustain these freedoms.

Mark Grief's The Age of the Crisis of Man: Thought and Fiction in America, 1933-1973 (2015) joins Marsden's and Hollinger's commendable treatments of the fusions and fissures of the Christian-Enlightenment story in America. For Grief,

${ }^{1}$ Marsden, Twilight of the American Enlightenment, 168-69. 
who is an assistant professor of literary studies at the New School, the common theme for post-World War II intellectuals and novelists was a shared scrutiny of the American consensus couched in anxiety about the nature, the direction, and the proper ideology of humanity. The anxiety generated what he calls a "maieutic" discourse, a static conversation stuck in grandiose abstractions. In the case of postwar intellectual culture, thinkers of the era raised big questions and poignant, if generalized, observations about "man" but delivered nothing more.

Marsden thinks they delivered a little more than Grief but they were the last group of intellectuals to operate under the liberal Protestant-Enlightenment consensus. Since that time, however, he contends, "there is no one standard, underlying set of assumptions, including beliefs about the ultimate nature of reality and values, that all rational educated people can somehow be presumed to share."2 In a world like this, Marsden wants his Augustinian brand of Christianity treated equally in public life as a source of authority. Others, he acknowledges, will prefer another faith tradition or no faith tradition. To his mind, however, Enlightenment ideology dominates public life and merely tolerates Christian perspectives. The situation is ironic. The Enlightenment valuing of critical reason has augmented the fragmentation of authority, but its champions, Hollinger among them, often insist on it as the authority.

Apart from this ironic predicament, Marsden's first chapters question the Enlightenment's strength for organizing modern life at all. In this section, he surveys a range of thinkers - among them David Riesman, James Baldwin, Walter Whyte, Erich Fromm, Walter Lippmann, and Reinhold Niebuhr - to illustrate the 1950s scrutiny of and dissatisfaction with its Protestant-Enlightenment heritage. These thinkers shared grave concerns about the supposed 1950s religious revival and the concurrent commercialism, scientism, and instrumentalism of modern life. To them, these organizing principles provided no real glue or common purpose for American society. Instead, they found a shallow culture producing reflexive citizens who appeared to be too conformist, on the one hand, or too individualistic, on the other, or lost between these two poles. But, for Marsden, they offered no real alternative to the modern dilemma.

Their solutions sputtered, but Marsden appreciates their diagnosis of modernity's implications for American society. Lippmann's A Preface to Morals (1929) stands out within this field as the finest precursor to Marsden's worry about authority and pluralism. In a brilliant piece of writing, Lippmann argues that the "acids of modernity" - science, urbanization, and pluralism - burned away the staying power of liberal and conservative Protestantism. Lippmann further contends that the modern conditions that reduced transcendent belief to ashes are, however, no substitute for how we ought to live together. 
With religion discredited and no modern replacement for its edifying and unifying power, Lippmann asks, now what? In an observation no less relevant in 2015 than 1929, Lippmann writes, "[the modern man] finds it hard to believe that doing any one thing is better than doing any other thing, or, in fact, that it is better than doing nothing at all." Modern man may not believe in any "theory of the meaning and value of events," yet "he is none the less compelled to accept the events" without a "moral authority." The problem is clear: "how mankind, deprived of the great fictions, is to come to terms with the needs which created those fictions." 3 His observations bedevil Preface to Morals and haunt contemporary America.

This aimlessness unsettles Lippmann as does the prospect of Americans forming so many individualized authorities. He proposes a disinterested and universal humanism to fill the moral authority void. Few would contend Lippmann succeeded. Among others, Daniel Rodgers's Age of Fracture (2011) shows how, through the late twentieth century, particularism surged in American life. This trend "toward disaggregation" starves a nation hungry for connection and common purpose, something Lippmann anticipated and feared. ${ }^{4}$

Midcentury thinkers offered variations of Lippmann's "acids of modernity" thesis and, according to Grief, created the "age of the crisis of man." Their focal point, Grief argues, led nowhere. The frenzied concern about the state of man under what they understood to be the corrosive effects of technology and the unfulfilled promise of the Enlightenment became the tired refrain of the age. Grief calls it an "empty discourse" that ends in "unanswerability." The always elusive, unhelpful, and abstract question "what is man?" created intellectual stagnation. Typical of the age were psychoanalysts Erich Fromm's Man for Himself (1947) and Karl Menninger's Man against Himself (1956). Titles like these evoke Grief's "unanswerabiltiy" and his concern that the "age of the crisis of man" was a futile moment of intellectual hand-wringing. ${ }^{5}$

Grief groups these midcentury assessments of man under the term "reenlightenment." He defines it not as a revival or "Second Enlightenment" but a loose confederation of intellectuals intent on a "humbler effort to restore the project of human liberation ... without the grandiosity or vulnerability of the earlier age's vision." Arbiters of this re-enlightenment could be religious or not and tilt toward or away from the Enlightenment.

\footnotetext{
${ }^{3}$ Walter Lippmann, A Preface to Morals (New Brunswick, NJ: Transaction Publishers, 1989) 4, 9, 144; Marsden, Twilight of the American Enlightenment, 50.

${ }^{4}$ Daniel T. Rodgers, Age of Fracture (Cambridge, MA: Belknap Press of Harvard University Press, 2011) 5.

${ }^{5}$ Mark Grief, The Age of Crisis of Man: Thought and Fiction in America, 1933-1973 (Princeton, NJ: Princeton University Press, 2015) 12, 316-30. Throughout this article, the non-inclusive male pronoun "man" appears. This is an exception to Harvard Theological Review's preference for inclusive language. The exception granted here corresponds to Grief's title and usage as well as the immediate post-World War II context where the use of "man" predominated.

${ }^{6}$ Ibid., 23.
} 
Grief's re-enlightenment is Marsden's twilight of the Enlightenment. Marsden, like Grief, notes that thinkers of that era offered no genuine alternative to the modern reorientation of life in the twentieth century. They were moderates who "had no solutions beyond more of the same," a chastened consensus about the value of science, reason, individualism, and progress for American equilibrium. ${ }^{7}$

Both Marsden and Grief want out of the impasse. Marsden opts for Kuyperianism. Grief simply wants out. In Grief's view, for all its intelligence, midcentury intellectual culture amounted to so many theories of man dancing on the head of a pin. This discourse of "the crisis of man," severed from actual sayings and doings of humans, restricted thought to an ethereal intellectual prison.

Grief fears contemporary scholarship is still locked down. The present infatuation with "posts" - postmodernism, posthumanism, post-secularism, and post-history — expresses a false urgency and similarly narrows inquiry by the fact that they "are all parts of the same thing." Beyond the "posts," he argues that climate change follows the inhibiting crisis rhetoric and method. Grand discussions about climate change occur, but they are no more than that. They spur us to inaction, satisfied that we have thought about the big problems of self and society. ${ }^{8}$

Grief's encyclopedic survey of the discourse of man ends in his own declaration of a crisis about the crisis of man. He orders such inquiry to "Stop!" Instead of theories of man, Grief advocates for the practices of man. Scholars should analyze and answer "questions of concrete value . . . and find the immediate actions necessary to achieve an aim. "9 Grief's new command is John Dewey's old one.

Marsden's book begins where Grief's ends. His review of postwar intellectual stasis serves as a long preface-perhaps too long - to his real aim: criticism of liberal and conservative Protestant accommodation of the Enlightenment and their failed religious pluralism. Overall, both traditions accepted their American Enlightenment birthright. And like family members they expressed their common ancestry differently and antagonistically. Liberal Protestants deferred to advances in natural science - evolution and geological time - and to social scientific approaches to the history of Christianity and the Bible. Conservative Protestants rejected those aspects of modern thought in favor of sola scriptura, but they adopted modern notions of individualism, free-market capitalism, and American exceptionalism. For Marsden, they each conceded too much of Christianity to the Enlightenment, and then they took out their differences on each other.

\footnotetext{
${ }^{7}$ Marsden, Twilight of the American Enlightenment, xvi.

${ }^{8}$ Grief, The Age of the Crisis of Man, 316-30.

${ }^{9}$ Ibid., 328.
} 
Marsden tells his story of liberal Protestantism through the life and career of theologian Reinhold Niebuhr. Hollinger does the same. Their respective spotlights on Niebuhr join a decade-long cascade of scholarly and mainstream references to the theologian's legacy. With few exceptions, the attention caricatures Niebuhr. Both Marsden and Hollinger follow the rule, not the exception. ${ }^{10}$

Marsden splits his opinion of Niebuhr. He credits Niebuhr for criticizing Enlightenment overestimations of the power of science, reason, and technology to solve complex social and political problems. Ultimately, however, he dismisses Niebuhr as a representative of a "generalized Christianity" that granted too much authority to natural science and "offered little to challenge most of the secularizing trends that he himself identified."

Marsden bases his interpretation of Niebuhr upon a conventional "atheists for Niebuhr" argument. On this view, admiration and appropriation of Niebuhr by Arthur Schlesinger, Jr., and other so-called "atheists for Niebuhr," questions the Christian character of his work. If atheists could adopt Niebuhr's criticism of American self-righteousness and drop his Christianity, the reasoning goes, then Christianity must be non-essential to his thought.

The existence of "atheists for Niebuhr" says less about Niebuhr and more about Schlesinger and company. Hollinger stresses this point in Cloven Tongues. He notes that Morton White, the Harvard philosopher who coined the phrase, meant it disapprovingly. White could not understand how there could be any such thing as an "atheist for Niebuhr" given, as Hollinger puts it, the "God and Jesus talk" that underpinned Niebuhr's thought. ${ }^{12}$

Hollinger's rejection of the "atheists for Niebuhr" argument is not a defense of the theologian. It is a prelude to a bigger target-Niebuhr as such. Cloven Tongues concludes by censuring Niebuhr as simultaneously too Christian and not Christian enough. On the former count, Hollinger criticizes what he calls Niebuhr's sectarianism, which privileged Christianity as the ultimate source of truth. This curious analysis begs the question: Would Hollinger fault a secularist for privileging secular thought? On the latter count, Hollinger, like Marsden, regards Niebuhr as a liberal Protestant who "was indeed more worldly, more secular" than most of his ecumenical contemporaries and consequently facilitated secularization more than he challenged it. ${ }^{13}$

Hollinger pushes this second argument too far. He implies that Niebuhr did not believe much of what he said about Christianity and its relevance for the modern world. "Might Niebuhr have always retained," writes Hollinger, some "suspicion

${ }^{10}$ The late John Patrick Diggins argued Niebuhr's legacy "continues to be misconstrued in the service of flawed political ends," and he insisted that Niebuhr "was a realist because he was religious" (John Patrick Diggins, Why Niebuhr Now? [Chicago: University of Chicago Press, 2011] 5, 71).

${ }^{11}$ Marsden, Twilight of the American Enlightenment, xxvi, 118-22.

${ }^{12}$ David Hollinger, After Cloven Tongues of Fire: Protestant Liberalism in Modern American History (Princeton, NJ: Princeton University Press, 2013) 213.

${ }^{13}$ Ibid., 220. 
that the Christian project could only do so much for humankind?" His Christian generalizations "could provide a religious cover ... a way of holding onto the faith for a while longer, enabling it to do what good it could, but not actually asking it to do very much." 14

These conjectures feed Hollinger's claim that no "Protestant intellectual of his time was more proud than Reinhold Niebuhr of his worldly wisdom." 15 As evidence, Hollinger cites Niebuhr's biblical epigraph in The Children of the Light and the Children of Darkness (1944). The quotation taken from Luke 16:8 reads, "The children of this world are in their generation wiser than the children of light." Hollinger interprets Niebuhr as "a child of this world, and of his generation." No doubt he was a child of his generation - everyone is - but Hollinger misinterprets Niebuhr's use of this quotation.

Niebuhr interprets the children of the light as naïve liberals who overestimate human innocence and goodwill. He defines the children of this world as children of darkness, the moral cynics of history who are "wise, though evil, because they understand the power of self-interest." ${ }^{16}$ For the rest of the book, Niebuhr inveighs against children of light (sentimental optimists) and children of darkness (pessimistic cynics).

Marsden's and Hollinger's Niebuhrian digressions unnecessarily dampen their arguments. Marsden's ultimate dismissal of Niebuhr, even if some of his criticisms are warranted, cuts off a domestic resource for his Kuyperian argument. For his part, Hollinger may have reasonable grounds to question Niebuhr's negotiation between Christianity and secularism, but his speculations reduce to ad hominem.

If Marsden and Hollinger share a perspective on Niebuhr, they also agree that conservative evangelicalism fails as a constructive contribution to American public life. Hollinger does not dwell on this point, but it is a clear assumption of his text. ${ }^{17}$ For his part, Marsden reprimands Christian right-wingers who uncritically champion America as a Christian nation. This vision, past and present, ignores the evangelical synthesis of Christianity with American Enlightenment values of "self determination, and free enterprise" and degenerates into us-them rhetoric that divides America into "Christian" and "non-Christian." Conservative Christians of this type, Marsden points out, have been unable to follow a foundational precept of their own tradition: "to do the same unto others as they would have done unto themselves." ${ }^{18}$

${ }^{14}$ Ibid., 222.

${ }^{15}$ Ibid., 223.

${ }^{16}$ Reinhold Niebuhr, The Children of Light and the Children of Darkness: A Vindication of Democracy and A Critique of Its Traditional Defense (New York: Charles Scribner's Sons, 1944) 10.

${ }^{17}$ Hollinger, Cloven Tongues, 39, chs. 8 and 9.

${ }^{18}$ Marsden, Twilight of the American Enlightenment, 149, 150; see also, 144-48. 
Having established that religious pluralism suffers in the hands of both liberal and conservative American Protestants, Marsden turns to the distinctive religiouspolitical career of Abraham Kuyper. Marsden begins his account of Kuyper by noting the significant differences between Kuyper's Dutch context and that of the twenty-first century US. The Netherlands differed dramatically from the US by its homogeneity, multi-party political system, and comfort with hierarchical authority. These contrasts, he argues, offer a framework for rethinking the American approach to pluralism. Yet the disparities Marsden offers, including America's diversity, twoparty stranglehold, and extreme discomfort with hierarchy, raise too many questions about the relevance of a Kuyperian model of religious pluralism for America.

Marsden's Kuyperian alternative survives these differences in one respect. Kuyper's significance for America lies in his anticipation of the postmodern world of competing narratives. Marsden summarizes, "Kuyper insisted that reason, natural science, and methodological naturalism were not ideologically neutral ... [they] operated within the framework of the faith, or higher commitments, of the practitioner." 19 In other words, like Kuyper, the postmodern world treats-in theory, anyway - all positions as normative expressions, "higher commitments," that dictate how life ought to be led.

Marsden practices what Kuyper preaches. At the outset of the book, he discloses his "Augustinian Christian" perspective and hopes it provides for constructive dialogue with those who do not share it. Such "frank recognition of differences" between the ultimate commitments of the religious and irreligious, he argues, will open up "understandings and insights that we can hold in common." ${ }^{20}$ Without this honest recognition of the normative bias of all viewpoints, Marsden contends, pluralism will languish and religious voices will remain unjustifiably "second class" in modern public discourse. ${ }^{21}$

Marsden is correct that there is nothing "second class" about religion. His straightforward assertion of the ultimate concerns and normative claims all people make about and upon reality is welcome and refreshing. We are, to extend a phrase from biblical scholar Walter Brueggemann, "selective fundamentalists" in the truths we hold and advance for others to follow. Still, Marsden somehow misses that American Christians wield first-class power in contemporary America. Presidents, let alone most elected officials, cannot win office without a Christian testimonial. As Hollinger notes, "Christianity continues to be the cultural norm, not the exception, in the United States." 22 On this point, Hollinger settles the issue.

${ }^{19}$ Ibid., 165.

${ }^{20}$ Ibid., xxix.

${ }^{21}$ Ibid., 175; see also, Robin Lovin, Reinhold Niebuhr and Christian Realism (Cambridge, UK: Cambridge University Press, 1995) ch. 1.

${ }^{22}$ Hollinger, Cloven Tongues, 198. 
Hollinger knows he is not without a norm. Like Kuyper, but more like Peter Novick, ${ }^{23}$ Hollinger ruminates on how the subjective impacts "objective" inquiry. In an autobiographical essay recounting his Anabaptist heritage and subsequent atheism at Berkeley, Hollinger asks: "When does a personal frame enable a historian to see historical realities that others might not see, and when does it become, instead, a bias?"24

It is not a matter of when but how a personal frame influences a vision of reality. All positions carry an "ideological taint." Scores of thinkers, from James Madison to Karl Marx to Reinhold Niebuhr, have observed the "impurity" and rationalizations of human thought. Madison put the matter succinctly: "As long as the connection subsists between his reason and his self-love, his opinions and his passions will have a reciprocal influence on each other." ${ }^{25}$ Thomas Kuhn, an author both Hollinger and Marsden cite, understood this from another angle. He established that paradigms shift and so do we.

No one avoids thinking their position, their orthodoxy, is less tainted than another. Marsden and Hollinger are no different, nor should they be. For Marsden, it is Augustinian-Kuyperian Christianity. For Hollinger, it is secular reason via the Enlightenment.

They may have their preferences, but also they know of the interdependence and mutual benefit of Christianity and the Enlightenment in modern Western history. With that lineage, writes Hollinger, individuals in the West fall along the continuum of faith and reason as "a matter of degree and emphasis."

Those degrees and emphases matter, and they are the stuff of conflict. Hollinger wants no part of Kuyperian pluralism. He has had "enough already" of argumentslike Marsden's - that treat scientific thought as "one of a number of 'paradigms.'” He resists such paradigmatic equality, especially on university campuses, for three reasons. First, Christianity cannot furnish proper evidence for its claims. Second, it has a history of evils. Third, Christian scholars emphasize moral formation too much and disciplinary content too little. ${ }^{27}$

Hollinger's objections do little more than submit faith to the reason side of the continuum. These understandable, if conventional, arguments lead, to borrow from Grief, nowhere. They are easily questioned and reversed. Twenty-first-century Enlightenment philosophes - from the natural sciences to the social sciences - have drunk deeply from the Kool-Aid of evidence. The evidence that counts, moreover, is evidence based on Enlightenment standards. These standards are important, the

${ }^{23}$ Peter Novick, That Noble Dream: The "Objectivity Question" and the American Historical Profession (Cambridge, UK: Cambridge University Press, 1988).

${ }^{24}$ Hollinger, Cloven Tongues, 170.

${ }^{25}$ James Madison, Federalist \#10, Constitution Society, accessed November 16, 2015, http:// www.constitution.org/fed/federa10.htm.

${ }^{26}$ Hollinger, Cloven Tongues, 14.

${ }^{27}$ Ibid., ch. 9. 
best we have on certain subjects and arenas of life, but they hardly give a full picture of reality. For instance, the standards automatically discount Christian "evidence." They also discount those who believe that Christianity is not based on evidence. Empirical evidence, of course, is the opposite of faith.

The "evils" of the Protestant hegemony are real. Christianity has much to answer for and apologize for. But so too does the secular Enlightenment. On the one hand, the typical allusion to two thousand years of Christian violence and oppression stands as evidence for its good riddance. On the other hand, an account of violence and oppression rooted in Enlightenment thought - all the more troubling for its shorter duration - stands as evidence for its good riddance. ${ }^{28}$ This scorecard history ends in unhelpful "better or worse" arguments and leads, as Marsden knows, to culture wars.

Hollinger's third concern about the sacrifice of content for formation recalls Max Weber's classic "Science as a Vocation." Weber warns against "the prophet and the demagogue" 29 in the lecture hall. It is a fair and important warning, and neither Marsden nor Hollinger would endorse such overt punditry - be it from Christian or Enlightenment sources.

Yet formation occurs on university campuses. It happens through student affairs divisions and classrooms governed by the modern Enlightenment methods that deliver content. But what is that content? For student affairs, it turns on social scientific views of leadership, community service, and inclusivity. The classroom prizes, with some variation, instrumentalism, deconstruction, and individualism. Weber was fine with that. "The fate of our times is characterized by rationalization and intellectualization, and above all, 'disenchantment of the world." "30 Hollinger is fine with that too.

Most students are not. They come from or want something more. They enroll at thousands of universities, even Berkeley, under the influence of Christianity or another religious system. Many of those without a religious background arrive on campus with big existential questions haunting them. Disenchanting content that "frees" the individual from tradition and toward cosmopolitanism addresses few of these concerns. ${ }^{31}$

${ }^{28}$ The realities and horrors of Leninism-Stalinism, Maoism, modern racism, eugenics, and exploitative capitalism come to mind.

${ }^{29}$ Max Weber, "Science as a Vocation," in From Max Weber: Essays in Sociology (ed. H. H. Gerth and C. Wright Mills; New York: Oxford University Press, 1946) 129-56, 146.

${ }^{30}$ Ibid., 155.

${ }^{31}$ Tim Clydesdale, The Purposeful Graduate: Why Colleges Must Talk to Students about Vocation (Chicago: The University of Chicago Press, 2015). 
Marsden does not object to the presence of these formative sources per se but wonders why we are satisfied with formation on modernity's terms alone. He effectively asks: why not cosmopolitanism inclusive of religious sensibilities? Marsden might have referenced the work of Jürgen Habermas here. Failing a more inclusive cosmopolitanism such as Habermas's, the Enlightenment conception of modern life begs major questions: freedom toward what? deconstruction? mindfulness? consumerism? individualism?

Fifty years ago, sociologist Phillip Rieff asked similar questions in his book The Triumph of the Therapeutic: Uses of Faith After Freud (1966). In his study, he analyzes the Enlightenment-secular culture as a new moral demand system with a therapeutic ethic. Such a culture, he argues, placed the mental and physical comfort of the self at its center, creating generations born "to be pleased," uncommitted and uninhibited. It was Lippmann's diagnosis three decades later.

Rieff's dismay about the cultural revolution of midcentury exemplifies Marsden's and Grief's reviews of midcentury intellectuals. He joins the diagnosticians of American life who offer no alternatives. Rieff claims nothing more for his account of the new culture. Still, he did not like what he saw, and his observations sound eerily familiar. He wonders about the stability of a society "when its members must stimulate themselves to feverish activity in order to demonstrate how alive they are ... vacillating between dead purposes and deadly devices to escape boredom." This Enlightenment-therapeutic culture was indeed a "new religiosity." His observations about it, although offered five decades ago, cut to the bone of a selfie culture with earbuds in, scrolling through a screen, guided by bucket lists, big data, TED talks, and one thing after another. Rieff worried then, and would certainly worry now, about Americans shaped by religions of the self. He thought the therapeutic-infused Enlightenment produced knowers without authority or wisdom. ${ }^{32}$

Marsden, Hollinger, and Grief worry no less than Rieff. They worry because they understand that competing orthodoxies, which are competing worries, shape history. Marsden worries about what counts as authority. Hollinger worries America has too many Christians claiming too much authority and wisdom. Grief worries scholars abstract authority and wisdom into a discourse of oughts, "manifestos and credos, papers of declaration and prophecy, objurgations and reverences," which ends in a still life of humanity. ${ }^{33}$

My worry for America originates in Christian suspicion of our culture. My late father, a Lutheran pastor in the Evangelical Lutheran Church in America, taught me that ideologies, Christian, Enlightenment, and beyond, rarely produce trustworthy authority or wisdom. This view originates from the human tendency to ascribe too

\footnotetext{
${ }^{32}$ Philip Rieff, The Triumph of the Therapeutic: Uses of Faith After Freud (Wilmington, DE: ISI Books, 2006) 8, 208.

${ }^{33}$ Grief, The Age of the Crisis of Man, 330.
} 
much authority to the self: to treat the self as a god. He owed this perspective, as I do, to Augustine, Luther, Kierkegaard, Niebuhr, Becker, and so many more - not least of all the Reverend Martin Luther King, Jr.

King features prominently, if briefly, in Marsden's, Hollinger's, and Grief's studies. Marsden applauds King's synthesis of Christian belief and America's founding ideals. Why he prefers Kuyper to King is never clear. He intimates that King's vision of pluralism died with him, and the rights conversations following his assassination splintered along lines of race, gender, and sexual orientation. But that is not King's fault.

Hollinger uses King to frame his book. Similarly to Marsden, he cites King as an example of Protestant Christianity and the Enlightenment. King then becomes Hollinger's foil for his own theme. He suggests, "not everyone . . . understands the relation between the two [Christianity and Enlightenment] in quite the same terms. And there are others who have depicted the relation as one of deep tension, even hostility." ${ }^{4}$ This may be true, but it is not King's fault.

For Grief, King's gravity owed much to Niebuhr. The theologian's doctrine of man leavened King's optimism and "furnish[ed] a realism and a sort of fortitude in confrontation with the depths of depravity of black Americans' segregationist opponents." At the same time, King authenticated Niebuhr. He applied and lived Niebuhr's thought during an all too real "crisis of man." Grief makes these observations and moves on, dropping King in as a prophetic representation of the discourse of man. ${ }^{35}$

King's public work and ministry is much more than a preface to identity politics or tensions between Christianity and the Enlightenment or an admirable contribution to the "age of the crisis of man." Rather, his civil rights work intersected with the worst and best of Christianity, the Enlightenment, and humanity. King and his fellow African Americans suffered violent racism by the thoughts and actions of humans who justified their cause on the basis of Christian and Enlightenment precepts. King and the movement also applied ideas from these same traditions that accelerated their liberation.

In the end, King's careful negotiation of Christianity, the Enlightenment, and the value of "man" brought a historic breakthrough for freedom and pluralism. His triumph owed more to Christian authority. Drawing on the doctrine of original sin and Niebuhr, King believed all humans found a way to abuse one another individually and collectively. ${ }^{36}$ In short, humanity was the problem-Christian, Enlightened, and otherwise. What could be more plural than that?

${ }^{34}$ Hollinger, Cloven Tongues, 2-3, 202.

${ }^{35}$ Grief, The Age of The Crisis of Man, 262-263.

${ }^{36}$ Martin Luther King, Jr., "The Drum Major Instinct," in A Testament of Hope: The Essential Writings And Speeches of Martin Luther King, Jr. (ed. James M. Washington; San Francisco: Harper Collins, 1986), 259-267. 